\title{
SCC with high volume of fly ash content
}

\author{
Anton Bakhrakh ${ }^{1}$, Artyom Solodov ${ }^{1}$, Oksana Larsen $^{1, *}$, Vitaly Naruts ${ }^{1}$, Olga Aleksandrova ${ }^{1}$, \\ and Boris Bulgakov ${ }^{1}$ \\ ${ }^{1}$ Moscow State University of Civil Engineering, Yaroslavskoe shosse, 26, Moscow, 129337, Russia
}

\begin{abstract}
Self-compacting concrete is a very perspective building material. It provides great benefits during the construction of heavily reinforced buildings. SCC has outstanding properties such as high flowability, dense structure and high strength due to specific quality of aggregates, fillers, their proportion in mix, use of polycarboxylate-based superplasticizers. Main disadvantages of SCC are high price and the difficulty of obtaining a proper mix. Use of fillers, such as fly ash type F, is a way to make SCC cheaper by replacing part of cement. Fly ash also provides some technological and operating advantages. In this paper the influence of high volume ( $60 \%$ from cement) fly ash type $\mathrm{F}$ on the properties of concrete mixture and hardened concrete is investigated. The result of the work shows the possibility of reduction the cost of SCC using ordinary fillers and high amount of fly ash. The investigated SCC has low speed of hardening (7-day compressive strength at the range of $41.8 \mathrm{MPa}$ ) and high volume of entrained air content (3.5\%).
\end{abstract}

\section{Introduction}

Self-compacting concrete is a concrete which can be placed and compacted in reinforced constructions without any vibration efforts [1]. SCC has very high flowability and at the same time cohesiveness enough to exceed bleeding or segregation. Self-compacting concrete provides such benefits as reduction of construction time and labour cost, refusal of vibration, reduction of noise pollution, high compressive strength and dense structure.

SCC mixture can be obtained using high amount of cement, high quality aggregates, microfillers such as fly ash, slag, metakaolin, quarry dusts and superplasticizers. The amount of cement paste in SCC is increased and amount of aggregates is limited to achieve flowability. Microfiller is added to exceed segregation or bleeding and to reduce the dosage of expensive superplasticizer, due to round shape, which produces extra flowability $[2,3]$.

High dosage of cement and superplasticizer causes high price of self-compacting concrete. Introduction of high amount of fly ash can decrease the cost of the SCC.

Fly ash has pozzolanic activity, produces not only technological and economical benefits, but also operating advantages such as high compressive strength and corrosion resistance [4].

Previous investigations show that the maximum size of coarse aggregate should be 10 $\mathrm{mm}$ and fine aggregate with fineness modulus of $1.25[5,6]$.

* Corresponding author: larsen.oksana@mail.ru 
The present work investigates the ability of obtaining SCC using ordinary aggregates (crushed granite with a maximum size of $20 \mathrm{~mm}$ and quartz sand with fineness modulus of $2.5)$ with $60 \%$ type F fly ash.

\section{Materials and mixture composition}

During experiments 12 mixes with different amount of superplasticizer and water/cement ratio were obtained to get needed flowability and exceed bleeding.

\subsection{Cement}

Cement used in this study was Ordinary Portland Cement type CEM I 42.5R Mordovcement with content of $\mathrm{C}_{3} \mathrm{~A}<8 \%$ and $\mathrm{C}_{3} \mathrm{~S}>55 \%$. Mechanical properties, chemical and mineralogical composition of cement are presented in Table 1.

Table 1. Mechanical properties, chemical and mineralogical composition of cement.

\begin{tabular}{|c|c|c|c|c|c|c|}
\hline \multicolumn{7}{|c|}{ Mechanical properties } \\
\hline \multirow{2}{*}{$\begin{array}{c}\text { Standard } \\
\text { consistence, \% }\end{array}$} & \multirow{2}{*}{\multicolumn{2}{|c|}{$\begin{array}{c}\text { Time of setting, } \\
\text { min }\end{array}$}} & \multicolumn{3}{|c|}{ Compressive strength, $\mathrm{MPa}$} & \multirow{2}{*}{$\begin{array}{c}\text { Expansion, } \\
\text { mm }\end{array}$} \\
\hline & & & 2-day & & 28-day & \\
\hline $26.0-28.0$ & 160 & & 23.0 & & 51.7 & 0 \\
\hline \multicolumn{7}{|c|}{ Chemical composition of cement } \\
\hline $\mathrm{SO}_{3}$ & Admixtures & & Loss on ignition & & luble residue & $\mathrm{Cl}^{-}$ \\
\hline 2.92 & 4.34 & & 1.27 & & 4.17 & 0.006 \\
\hline \multicolumn{7}{|c|}{ Mineralogical composition of cement } \\
\hline $\mathrm{C}_{3} \mathrm{~S}$ & $\mathrm{C}_{2} \mathrm{~S}$ & & & & $\mathrm{CaO} / \mathrm{SiO}_{2}$ & $\mathrm{MgO}$ \\
\hline 59.97 & 16.55 & & & & 3.01 & 1.12 \\
\hline
\end{tabular}

\subsection{Fly ash}

Fly ash used in this work was ordinary fly ash from Cherpetskaya thermal power station, containing $\mathrm{CaO}$ of $2.67 \%$ and $\mathrm{MgO}$ of $1.52 \%$, loss on ignition of $6.52 \%$ and specific surface of $250 \mathrm{~m}^{2} / \mathrm{g}$.

\subsection{Coarse aggregate}

Crushed granite with a maximum size of $20 \mathrm{~mm}$ and specific gravity of $2700 \mathrm{~kg} / \mathrm{m}^{3}$ was used as coarse aggregate. The amount of flake form coarse aggregate was $20 \%$. The Sieve residue (in \%) of coarse aggregate is shown in Table 1.

Table 2. Grading of coarse aggregate.

\begin{tabular}{|c|c|}
\hline Sieve size, $\mathrm{mm}$ & Percentage passing, $\%$ \\
\hline 20 & 96.9 \\
\hline 10 & 26.6 \\
\hline 5 & 2.8 \\
\hline 2.5 & 1.0 \\
\hline bottom & 0.0 \\
\hline
\end{tabular}

\subsection{Fine aggregate}


Quartz sand with specific gravity of $2640 \mathrm{~kg} / \mathrm{m}^{3}$ and fineness modulus equal to 2.5 was used as fine aggregate. The Sieve residue (in \%) of sand is shown in Table 3.

Table 3. Grading of fine aggregate.

\begin{tabular}{|c|c|}
\hline Sieve size, $\mathbf{~ m m}$ & Percentage passing, $\%$ \\
\hline 5 & 96.2 \\
\hline 2.5 & 87.1 \\
\hline 1.25 & 76.8 \\
\hline 0.63 & 53.9 \\
\hline 0.315 & 21.9 \\
\hline 0.16 & 3.9 \\
\hline bottom & 0.0 \\
\hline
\end{tabular}

\subsection{Chemical admixture}

Superplasticizer BASF MasterGlenium 115, polycarboxylate-based superplasticizer, was used to obtain flowability and decrease water/cement ratio. Recommended dosage is from $0.2 \%$ to $2.0 \%$ of cement mass.

\subsection{Mixture composition}

In this research 12 mixtures of SCC with different amount of chemical admixture and water content were obtained in order to get needed viscosity, flowability and exceed bleeding. The first mortar included the following amounts of components: $360 \mathrm{~kg}$ of cement, $215 \mathrm{~kg}$ of fly ash, water $-180 \mathrm{~kg}$, fine aggregate $-750 \mathrm{~kg}$, coarse aggregate $-810 \mathrm{~kg}$ and $10.4 \mathrm{~kg}$ of superplasticizer. Fly ash/cement ratio was fixed to $60 \%$, superplasticizer $-1.8 \%$ of binder. For the experiment the 10 liters of mixture were prepared. Huge amount of admixture caused visible segregation and bleeding, slum flow test showed more than 800 $\mathrm{mm}$. Dosage of $1.4 \%$ from the mass of cementous materials also showed segregation. Next mortars included the amount of superplasticizer at the range from $0.6 \%$ to $1.5 \%$ by mass of cement with water/cement ratio equal to 0.32 .

Table 4. Final mixture composition.

\begin{tabular}{|c|c|}
\hline Materials & $\begin{array}{c}\text { Dosage of components, } \\
\mathrm{kg} / \mathrm{m}^{3}\end{array}$ \\
\hline Cement & 360 \\
\hline Fly ash & 215 \\
\hline Water & 183 \\
\hline Fine aggregate & 750 \\
\hline Coarse aggregate & 810 \\
\hline Plasticizer & 5.4 \\
\hline
\end{tabular}

\section{Results}

The obtained SCC mixture demonstrated positive technological properties without any bleeding and segregation. It possessed good flowability and had $550 \mathrm{~mm}$ slump flow, high density $\left(2255 \mathrm{~kg} / \mathrm{m}^{3}\right)$ and $3.5 \%$ of entrained air content. The developed concrete showed 
relatively high compressive strength within 3 days at the range of $23.1 \mathrm{MPa}$ while 7 and 28day compressive strength gave $41.8 \mathrm{MPa}$ and $71.5 \mathrm{MPa}$ respectively.

\section{Conclusions}

It was determined the optimal dosage of superplasticizer (1.5\% from the mass of cement) to achieve needed flow ability. It was investigated that addition $60 \%$ by mass of cement together with super plasticizer provides self-compaction without bleeding and segregation. At the same time it causes high volume of entrained air $(3.5 \%)$ in SCC mixture. The obtained SCC mixture included for one cubic meter of the concrete mixture: $360 \mathrm{~kg}$ cement, $215 \mathrm{~kg}$ - fly ash, $183 \mathrm{~kg}$ - water, $750 \mathrm{~kg}$ and $810 \mathrm{~kg}$ of fine and coarse aggregate respectively and $5.4 \mathrm{~kg}$ - super plasticizer. Such composition was selected in accordance with world experience $[7,8,9]$ and mathematical patterns to achieve flow ability [10]. The designed SCC mixture demonstrated high early compressive strength. It can be explained by high water retention capacity on increase of the hydration degree by creating a high dense homogenous structure of the concrete [10]. Use of fly ash in SCC gives economical efficiency due to fly ash's low price, reduces labour cost and time of construction [11].

\section{References}

1. H. Okamura, M. Ouchi, Journ. of Adv. Concr. Techn., 1, 5 (2003)

2. T. Proske, S. Hainer, M. Rezvani, C.-A. Graubner, Cem. and Concr. Res., 51, 38 (2013)

3. H.J.H. Brouwers, H.J. Radix, First International Symposium on Design, Performance and Use of Self-Consolidating Concrete SCC'2005, 21 (2005)

4. N. I. Makridin, V. I. Kalashnikov, K. N. Mahambetova, Technology of concrete, building products and construction (in Russian - Tekhnologiya betona, stroitelnykh izdelii i konstruktsii) (2014)

5. M. Karamloo, M. Mazloom, G. Payganeh, Constr. and Build. Mat., 123, 508 (2016)

6. S. Barbhuiya, Constr. and Build. Mat., 25, 3301 (2011)

7. J. Zhang, X. A, D. Nie, Con. and Buil. Mat., 116, 355 (2016)

8. A. F. Bingol, I. Tohumcu, Mat. and Des., 51, 12 (2013)

9. W. Wongkeo, P. Thongsanitgarn, A. Ngamjarurojana, A. Chaipanich, Mat. and Des., 64, 261 (2014)

10. S. Girish, R.V. Ranganath, J. Vengala, Constr. and Build. Mat., 24, 2481 (2010)

11. F. V. Muellera, O. H Wallevika, K. H Khayat, Cem. and Concr. Comp., 54, 117 (2014) 